\title{
ELBOW WRAP IMPROVES BENCH PRESS PERFORMANCE IN TRAINED SUBJECTS
}

\author{
BANDA ELÁSTICA DE COTOVELOS MELHORA DESEMPENHO DO SUPINO RETO EM SUJEITOS TREINADOS
}

ORIGINAL ARTiCLE

BANDA ELÁSTICA DE CODOS MEJORA EL RENDIMIENTO DEL SUPINO RECTO EN SUJETOS ENTRENADOS

Original Article

ARTIGO ORIGINAL

Artículo Original

Willy Andrade Gomes

(Physical Education Professional)

Enrico Gori Soares²

(Physical Education Professional)

Josinaldo Jarbas da Silva

(Physical Education Professional)

Fábio Sisconeto de Freitas ${ }^{2}$

(Physiotherapist)

Roberto Aparecido Magalhães²

(Physical Education Professional)

Charles Ricardo Lopes ${ }^{3}$

(Physical Education Professional)

Paulo Henrique Marchetti ${ }^{4}$

(Physical Education Professional)

1. Universidade Nove de Julho, São Paulo, São Paulo, Brazil. 2. Universidade Metodista de Piracicaba, Departamento de Ciências do Movimento Humano, Piracicaba, São Paulo, Brazil.

3. Faculdade Adventista de Hortolândia, Piracicaba,

São Paulo, Brazil.

4. Department of Kinesiology,

California State University,

Northridge, California, USA.

\section{Correspondence:}

Paulo H Marchetti.

California State University.

Department of Kinesiology, 18111

Nordhoff Street, Northridge, CA,

USA. 91330-8287.

dr.pmarchetti@gmail.com

\begin{abstract}
Introduction: The elastic wrap is widely used by different types of athletes and recreational practitioners of strength training in order to improve weightlifting performance. Objective: The objective was to investigate the acute effects of elbow wrap on strength performance, absolute volume, and rating of perceived exertion/discomfort during the bench press (BP) exercise. Methods: The experimental protocol was divided into three laboratory sessions. At the first session, a bench press familiarization phase was performed with (EW) and without (WEW) elastic elbow wrap. During the second session, the 1RM test was carried out in the bench press exercise under both EW and WEW conditions. At the third session, the repetition maximum (RM) test at 70\% of 1RM (EW and WEW) was performed until concentric failure. After each session, subjects were consulted about their rate of perceived exertion (RPE), and discomfort (PSD). A paired student t-test was used to compare the values of 1 RM and RMs with and without elastic wraps. Descriptive analysis was used for RPE and PSD. Results: For the 1RM test, there was a significant increase for the EW condition when compared to WEW $(p<0.05)$. In the RMs test and absolute volume calculation, there was a significant increase for the EW condition $(p<0.05)$. RPE did not differ in any of the conditions tested ( $p>0.05)$. PSD presented a high degree of discomfort with elastic wraps in all conditions. Conclusion: Elastic elbow wraps increase the load lifted in the 1RM test, and the maximum number of repetitions during the BP exercise, and consequently, the absolute volume. The elastic elbow wrap does not alter the subjective perception of effort, but it increases discomfort during exercise.
\end{abstract}

Keywords: Performance; Force; Exercise.

\section{RESUMO}

Introdução: A banda elástica é muito utilizada por diferentes tipos de atletas e por praticantes de treinamento de força recreacionais, no intuito de melhorar o desempenho no levantamento de cargas. Objetivo: Investigar os efeitos agudos do uso da banda elástica de cotovelos no desempenho de força, no volume absoluto e percepção subjetiva de esforço durante o exercício supino reto livre. Métodos: Na primeira visita, foi realizada a familiarização com o exercício supino reto livre com banda (CB) e sem banda (SB) elástica de cotovelos. Na segunda visita, foi realizado o teste de $1 R M$ no exercício supino reto livre, nas condições CB e SB. Na terceira visita, foi realizado o teste de repetições máximas até a falha concêntrica (RMs) a 70\% de 1RM (CB e SB). Após cada teste, os sujeitos foram questionados quanto a sua percepção subjetiva de esforço (PSE) e de desconforto (PSD). Teste t de student pareado foi utilizado para comparar os valores de 1 RM e RMs, com e sem banda elástica. Para a PSD e a PSE foram utilizadas análises descritivas. Resultados: No teste de $1 R M$ foi verificado um aumento significante para a condição $C B$, quando comparado à condição $S B$ $(P<0,05)$. No teste de $R M$ s e cálculo do volume absoluto, foi verificado um aumento significante para a condição $C B$ $(P<0,05)$. A PSE não apresentou diferenças em todas as condições testadas $(P>0,05)$. A PSD apresentou alto grau de desconforto apenas com banda elástica em todas as condições. Conclusão: A banda elástica de cotovelos aumenta a carga levantada no teste de 1 RM e o número de repetições máximas durante o exercício supino reto livree, consequentemente, no volume absoluto. A banda elástica não altera a percepção subjetiva do esforço, mas aumenta o desconforto durante o exercício.

Descritores: Desempenho; Força; Exercício.

\section{RESUMEN}

Introducción: La banda elástica es muy utilizada por diferentes tipos de atletas y por practicantes de fuerza recreacionales con el fin de mejorar el desempeño de levantamiento de pesos. Objetivo: Investigar los efectos agudos del uso de la banda elástica de codos en el desempeño de la fuerza, en el volumen absoluto y percepción subjetiva de esfuerzo durante el ejercicio supino recto libre. Métodos: En la primera visita se realizó la familiarización con el ejercicio supino recto libre con banda (CB) y sin banda (SB) elástica de codos. En la segunda visita fue realizada la prueba de 1RM en el ejercicio supino recto libre, en condiciones CB y SB. En la tercera visita fue realizada la prueba de repeticiones máximas hasta la falla concéntrica (RM) al 70\% de 1RM (CB y SB). Después de cada prueba los sujetos fueron consultados en relación a su percepción subjetiva de esfuerzo (PSE) y de incomodidad (PSD). La prueba t de student pareada fue utilizada para comparar los valores de 1RM y RMs con y sin banda elástica. Para PSD y PSE se 
utilizó un análisis descriptivo. Resultados: Para la prueba de 1 RM se verificó un aumento significativo para la condición $C B$, en comparación con la condición $S B(P<0,05)$. En la prueba de $R M$ y cálculo del volumen absoluto fue verificado un aumento significativo para la condición $C B(P<0,05)$. La PSD presentó un alto grado de incomodidad apenas con banda elástica en todas las condiciones. Conclusión: La banda elástica de codos aumenta la carga levantada en la prueba de 1RM y el número de repeticiones máximas durante el ejercicio supino recto libre y, en consecuencia, en el volumen absoluto. La banda elástica no altera la percepción subjetiva de esfuerzo, pero aumenta la incomodidad durante el ejercicio.

Descriptores: Desempeño; Fuerza; Ejercicio.

\section{INTRODUCTION}

Many acessories and fittings are used in strength training in order to increase safety and/or physical performance. ${ }^{1,2}$ The elastic wrap in knees and elbows are widely used by athletes (powerlifers, weightlifters, strongmans), and even for recreational practitioners. ${ }^{3}$ The elastic wrap can be described as a band composed of polymeric material which is generally composed of polyester and elastomer, which when combined, have mechanical characteristics that assist the performance of subjects using it. ${ }^{2-4}$ The aid created by the elastic wrap on the joint effect is called "carry-over"1,2,4-9 being this effect based on the elastic potential energy accumulation during the repetitions, where the band suffer deformation.

Several studies have investigated the effects of using the elastic wrap in performance. ${ }^{4-9}$ Gomes et al., ${ }^{6}$ verified a 21 and 22\% increase in peak force during maximum isometric squatting with different elastic band models (Soft e Hard, respectively). Marchetti et al., ${ }^{9}$ also observed an increase in peak force during maximum isometric squatting, regardless of the technique of elastic wrap placement (in spiral: 10,8\% in " $X^{\prime \prime}: 13,6 \%$ ). Studies investigating the effect of knee elastic wrap during dynamic squatting demonstrated an increase in the overload raised in $19,8 \%{ }_{1}^{2}$ of the impulse on the bar, ${ }^{8}$ reduction of myoelectric activity of the vastus lateralis ${ }^{1}$ and alteration in the pattern of movement., ${ }^{1,8}$

So, although several studies showed an increase in performance when the elastic wrap was used, such studies only investigated its effects on the knee joint complex and during the exercise of the squat exercise. ${ }^{1,2,-9}$

Therefore, the objective of the present study was to investigate the acute effects of elbow wrap on maximal and submaximal strength performance, absolute volume and Rating of perceived exertion/discomfort during the bench press exercise. The main hypothesis considers that the use of elastic wrap of elbows increases the maximum and submaximal performance of the bench press exercise, as well as negatively affects the perception of effort.

\section{METHODS}

The sample consisted of 15 male subjects (age: 27,2 $\pm 5,5$ years; total body mass: $80,9 \pm 9,5 \mathrm{~kg}$; height: $174 \pm 6,3 \mathrm{~cm}$; bi-acromial distance: $38,6 \pm 2,4$ and practice time in force training: $5 \pm 2,9$ years). The sample size was calculated through a pilot study with individuals who had the same characteristics as were employed in the present study $(n=5)$. The 1RM test was used as the dependent variable, based on a significance of $5 \%$ and a test power of $80 \% .^{10}$ The inclusion criteria were: (I) healthy individuals trained in resistance training who performed the bench press exercise for at least one year in an uninterrupted manner, (II) individuals without any previous surgery on the upper limb and or trunk, (III) and without any ligamentous and osteomioarticular lesions in the upper limbs and/or trunk. All subjects were informed and signed the free informed consent form approved by the Research Ethics Committee (Protocol \#03/2014).

The subjects were instructed to abstain from any physical exercises for at least 72 hours prior to the three visits to the laboratory. At the first visit, it was requested personal data such as name, age, practice time in resistance training, upper limb dominance (based on preference in writing). ${ }^{11}$ Then, were collected the anthropometric data (height, total body mass and bi-acromial distance). Then, the subjects were asked about the estimated overload to perform a maximum movement during the bench press exercise. Next, a brief familiarization was performed in the bench press exercise with and without the use of elastic wrap of elbows. The familiarization consisted in performing the maximal strength test (1RM) using the overload estimated by the subjects, following the recommendations of Brown and Weir. ${ }^{12}$ Then, the maximal repetition test was performed until the concentric failure at $70 \%$ of the 1RM test for each experimental condition (with and without wrap). A 10 minute interval was used between conditions and tests.

On the second visit, the 1RM test was performed on the bench press exercise according to the guidelines of Brown and Weir. ${ }^{12}$ Later, the 1RM test was performed under conditions with elbow wrap (EW) and without elbow wrap (WEW) at random until the maximum overloads was found or until a total of five attempts were performed and with a range of 10 minutes.

At the third visit, subjects underwent brief warm-up (50\% of 1RM). Then, after a five minute interval, the 70\% 1RM (RM test) test was performed until the concentric failure in the EW and WEW conditions, randomly. The external overload used in the RM test, in both conditions, was the percentage based on the 1RM test without the elastic wrap of elbows. After the RM test, the subjects were questioned about their rating of perceived exertion (PSE) in the exercise and discomfort (PSD) in the elbow region.

The subjects performed the bench press, in dorsal decubitus, starting the movement with the elbows extended, with the thorax and the hip supported in the bank and thefeet on the ground. The definition of the grip width on the bar was performed using twice the bi-acromial distance of each subject. ${ }^{13,14}$ This handle was selected for providing the greatest force output in the bench press exercise ${ }^{13}$, and was demarcated as a benchmark for testing through the adhesive tape on the bar.

The placement technique of the elastic wrap was spiral (from outside to inside) described by Coutinho. ${ }^{2}$ The placement of the elastic wrap was always performed by the same researcher, as tight as possible. The elastic wrap had the following measures: 1,00 $00,08 \times 0,02 \mathrm{~m}$ and composed by $70 \%$ of polyester and $30 \%$ of elastodiene (Maba Murphy Confecções Ltda, Brasil).

The maximum movement test (1RM) was performed in each condition (EW and WEW), separately, according to the procedures of Brown and Weir. ${ }^{12}$ Initially, the subjects performed a specific warm-up, composed of two sets. In the first sets, 8 repetitions were performed with 50\% of the overload estimated for 1RM, and in the second sets of 3 repetitions were performed with $70 \%$ of the estimated overload for 1RM. Then, after 5 minutes the 1RM test was performed. Each subject had a maximum of 5 trials using a 5 minute interval between trials, and 10 minutes between conditions. The load increase ranged from 5 to $10 \%$ of the previously load lifted. To maximize the lifting capacity, it was adopted a handle for $200 \%$ of bi-acromial distance. ${ }^{13}$ The volunteers began the test with 
their elbows extended, lowered the bar to touch the chest, and thus returned to the initial position with elbows extended, at a cadence of controlled movement and self-selected by the subject. Attempts with partial repetitions were not considered valid. Subjects were systematically encouraged verbally in all attempts.

The maximal repetition (RM) test was performed in both experimental conditions in a randomized fashion, using the same pattern of motion performed during the 1RM test, at a 70\% intensity of 1RM, determined from the 1RM test without a wrap. The test was performed until concentric muscle failure, at a self-selected cadence, and 10 minute interval was used between conditions.

The Rating of Perceived Exertion Scale (PSE) was used from 0 to 10 immediately after performing each test (1RM and RMs) in each condition (with wrap and without wrap). After each condition, the subject was asked: "How was your workout?", And through the PSE a value of zero to ten was found, with zero being "rest" and 10 being the maximum intensity perceived for the exercise accomplished. 15,16

A Rating of Subjective Disconfort Scale (PSD) was used from 0 to 10 immediately after each test (1RM and RMs) in each condition (with and without wrap). After each condition the subject was asked: "What was your sensation of discomfort in the elbow region?" And through the PSD a value was found to be a value from zero to ten, where zero meant no discomfort and 10 maximum perceived discomfort. ${ }^{1,9}$

\section{Statistical analysis}

The normality and homogeneity of the variances were verified using the Shapiro-Wilk and Levene test, respectively. A paired Student's t test was used to compare the differences in the values obtained for the load lifted during the 1RM test, for the maximal number of repetitions (RM) performed in the RM test, and for the absolute volume with and without elastic wrap. A PSD and PSE were reported through a descriptive analysis using the mean and standard deviation (SD) of the mean. The effect size (d) was calculated using the Cohen formula and the results were based on the following criteria: $<0,35$ trivial effect; 0,35-0,80 small effect; 0,80-1,50 moderate effect; e >1,50 large effect, for recreationally trained subjects based on Rhea. ${ }^{17}$ Significance of $5 \%$ was used for all statistical tests using SPSS software version 21.0.

\section{RESULTS}

The number of laps of the elastic wrap on the elbow joint varied between 4 and 6 turns ( $5 \pm 0.37$ turns) in all subjects evaluated.

For the overload during the 1RM test, a significant increase in EW performance was observed when compared to WEW $(P<0.01 ; d: 0.47$ [small effect] $\triangle \%$ : 6.62) (Figure 1).

In the maximal repetition test until the concentric failure (RM), a significant increase in EW performance was verified when compared to the WEW condition ( $P<0.01 ; d: 1.35$ [moderate effect]; $\triangle \%$ : 21.8) (Figure 2a). For the absolute volume during the maximal repetition test until the concentric failure (RMs), a significant increase of the performance in the EW condition was verified when compared to the WEW condition $(P<0.01 ; d: 1.54$ [large effect]; $\triangle \%: 23.08)$ (Figure 2b). However, the use of the elastic elbows wrap did not change the PSE for the 1RM tests (EW:

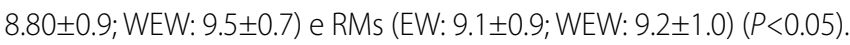

For PSE, there was no significant difference between conditions for the analyzed tests (1RM test [EW: 8.8 \pm 0.94 e WEW: $9.5 \pm 0.74]$ and RMs testes [EW: $9.1 \pm 0.99$ e WEW: $9.2 \pm 1.03])(P>0.05)$.

For the PSD at the elbow, the subjects reported a high degree of discomfort when performing the supine exercise with elastic band in both tests of maximum strength when compared to the condition without elastic wrap (EW: 1RM: $9.3 \pm 0.8$ and RMs: $9.2 \pm 1.3$; WEW: 1RM: $0.0 \pm 0.0$ and RMs: $0.0 \pm 0.0$ ).

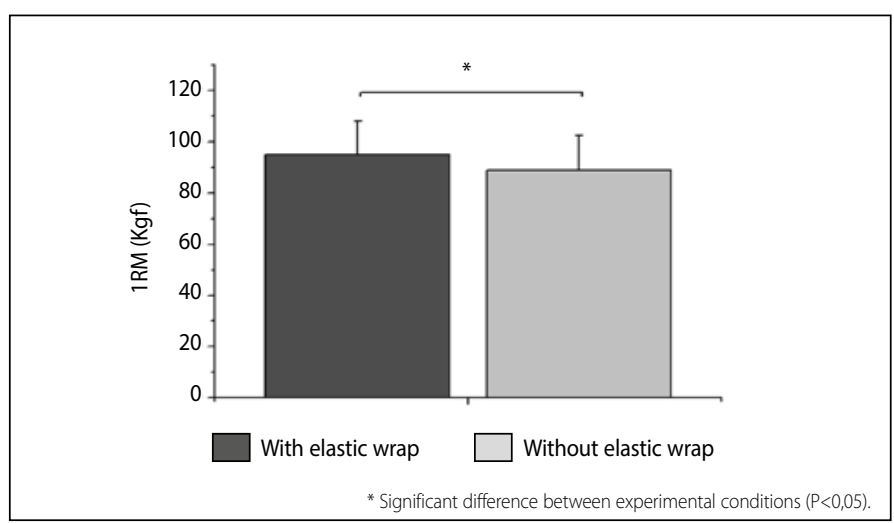

Figure 1. Mean and standard deviation of the overload lifted during the 1RM test.

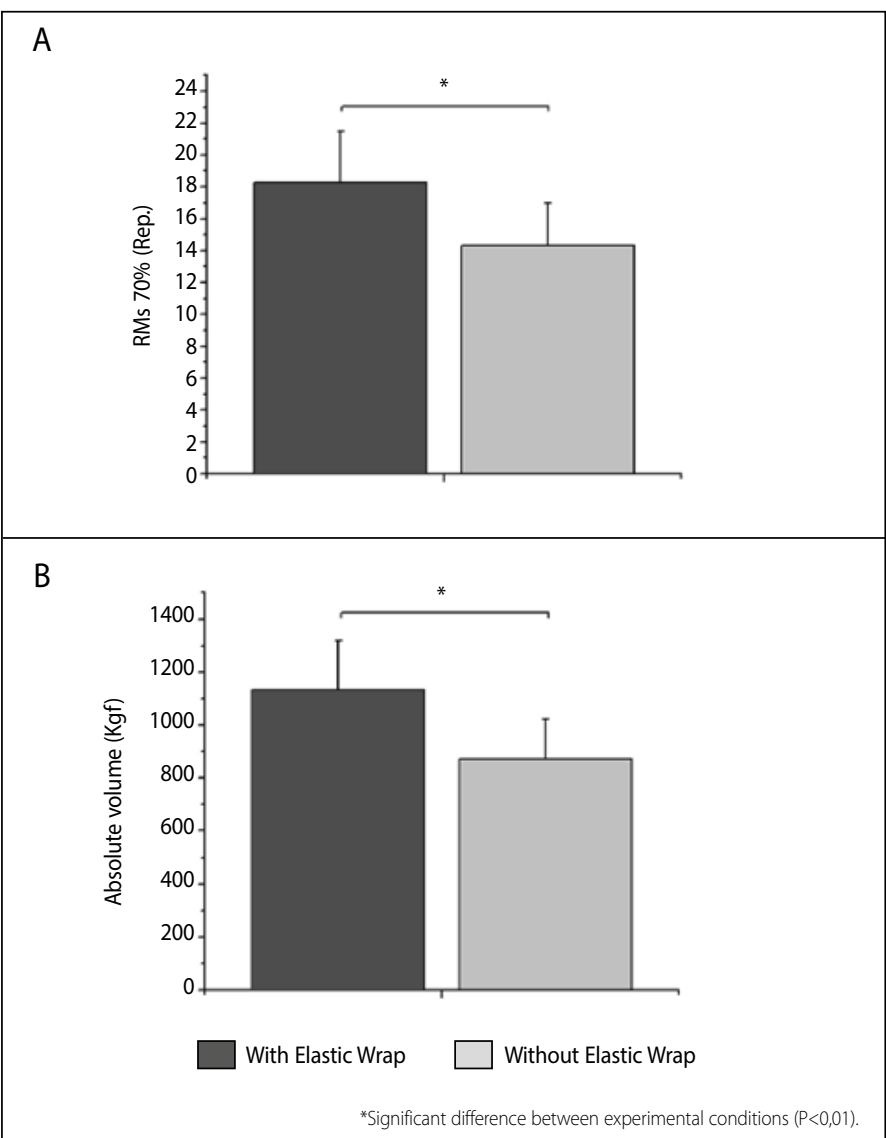

Figure 2. Mean and standard deviation of A) maximal number of repetitions (RM) and A) absolute volume during the RM test

\section{DISCUSSION}

The objective of the present study was to investigate the acute effects of elastic elbow wrap on maximal and submaximal strength performance, absolute volume, rating of perceived exertion and discomfort during bench press exercise. The main findings show a significant increase in overload in the condition with elbow wrap (EW) when compared to the condition without elbow wrap (WEW) in all tests performed (1RM and RMs), corroborating the main hypothesis of the study. In this way, the use of the elastic wrap at the elbow joint promoted an increase in lifting capacity in the bench press exercise. Possibly, the increased performance has occurred due to the mechanical aid produced by the elastic wrap, which when deformed in the descending phase of the exercise, accumulates elastic potential energy which is then transferred to the elbow joint assisting the concentric phase of the movement. ${ }^{2,3}$ Thus, the elbow extension capacity is increased and, consequently, the overload lifted, corroborating with studies that evaluated the effect of 
the use of the elastic band on the joint complex of the knee during the squat exercise. ${ }^{2,6,9}$

In the present study, the performance increase in the 1RM test was $6 \%$, whereas for the maximum repetition test (RMs) verified an increase in the number of repetitions and in the absolute volume of 21 and $23 \%$ respectively. Coutinho ${ }^{2}$ demonstrated an increase in performance of $19.8 \%$ during the dynamic squat exercise.Yet, Marchetti et al., ${ }^{9}$ and Gomes et al., ${ }^{6}$ observed increases of $10.8 \%$ and $22 \%$, respectively, in the peak isometric force during the maximal isometric knee exercise using a knee elastic wrap from the same manufacturer and model (Maba Murphy Confecções Ltda, Brasil, model: Hard).

Additionally, the differences found for the carry-over are based initially on the mechanical differences between the joints studied (elbow to knee), and for differences between the studies where the measurement of the carry-over effect was performed through a voluntary contraction test maximal dynamic (1RM); and in the study made by Gomes et al. ${ }^{6}$ and Marchetti et al. ${ }^{9}$ used isometric maximum voluntary contraction (CVMI) tests through a load cell. In addition, the difference in the length of the elastic wrap of elbows (1 meter) resulted in an average of five laps on the elbow joint, and for the elastic wrap on the knees (2 meters) the number of laps reported is approximately seven laps. ${ }^{6}$ At this way, possibly the largest number of laps resulted in an increase in the number of elastic fibers in parallel, increasing the resistance offered by the elastic wrap, increasing too the lifting capacity. ${ }^{6}$

The rating of perceived exertion (PSE) was not different between the conditions (EW and WEW) and test performed (1RM and RMs) (PSE 9). So, the elastic elbows wrap increased the overload during the $1 \mathrm{RM}$ and RM tests, however, the PSE remained unchanged, since it was mainly influenced by the intensity of the exercise performed. ${ }^{18}$ The results of the PSE, verified in the present study corroborate with the findings of Marchetti, et al., ${ }^{9}$ and Gomes et al., ${ }^{1}$ did not verify differences in PSE between EW and WEW conditions during the squat exercise.

Curiously, the subjects reported a high index of elbow discomfort when questioned about their subjective perception of discomfort (PSD 9), in both tests performed (1RM and RMs).

The results showed that the use of the elastic elbow wrap increased the performance of maximum strength and force resistance in the bench press exercise, however, such results cannot be extrapolated to chronic effects such as muscular hypertrophy or increased strength capacity.

For coaches and practitioners of force training, the use of the elastic elbows wrap can be used as a training strategy when the objective is to increase the maximum overload or the number of maximal repetitions performed, as well as the absolute volume of the bench press exercise . However, the increase in the perception of discomfort may be a limiting factor in the performance or use of the elastic elbows wrap.

\section{CONCLUSION}

The elastic elbow wrap increases the load lifted in the 1RM test and the maximum number of repetitions during the bench press exercise, and consequently, the absolute volume. The elastic wrap does not alter the subjective perception of effort, in contrast with the subjective perception of discomfort in the elbows that increases considerably.

All authors declare no potential conflict of interest related to this article.

AUTHORS' CONTRIBUTIONS: Each author made significant individual contributions to this manuscript. WAG (0000-0003-4223-8917)* and PHM (0000-0002-2016-936X)* were the main contributors to the design of the experiment, data collection, data analysis, and writing of the manuscript. EGS (0000-0002-8168-9828)*, Josinaldo Jarbas da Silva (0000-0003-2709-4468)*, FSF (0000-0003-4872-0077)*, RAM (0000-0002-6595-4230**, and CRL (0000-0003-4278-4969)* conducted the data collection and the critical review of the content. All the authors performed the final review of the manuscript and contributed to the intellectual concept of the study. ${ }^{*} \mathrm{ORCID}(\mathrm{Open}$ Researcher and Contributor ID).

\section{REFERENCES}

1. Gomes WA, Brown LE, Soares EG, Silva JJ, Silva FHDO, Serpa EP, et al. Kinematic and sEMG analysis of the back squat at different intensities with and without knee wraps. J Strength Cond Res. 2015;29(9):2482-7.

2. Coutinho M. De volta ao básico: powerlifting - treinamento funcional, esporte de alto rendimento e prática coporal para todos. São Paulo: Editora Phorte; 2011.

3. Gomes WA, Coutinho M, Marchetti PH. Revisão dos efeitos biomecânicos do uso da banda elástica no joelho durante o agachamento no levantamento básico. CPAQV. 2013;5(3):1-15.

4. Gomes WA, Ferreira AM, Marchetti PH. Comparação entre diferentes tipos de bandas elásticas de joelho: uma análise de suas características mecânicas e efeitos no treinamento de força. In: Zanesco A, editor. IX Congresso Internacional de Educação Física e Motricidade Humana XV Simpósio Paulista de Educação Física (VIII CIEFMH e XIV SPEF). Rio Claro, São Paulo: Motriz; 2015. p. 70-1.

5. Eitner JD, LeFavi RG, Rieman BL. Kinematic and kinetic analysis of the squat with and without knee wraps. J Strength Cond Res. 2011;25(1):S41.

6. Gomes WA, Serpa EP, Silva JJ, Correa DA, Silva FHDO, Neto FA, et al. Acute effects on maximal isometric force with and without knee wrap during squat exercise. Int J Sports Sci Coach. 2014;4(2):47-9.

7. Harman E, Frykman P. The effects of knee wraps on weightlifting performance and injury. Nat Strength Cond J. 1990;12:30-5.

8. Lake J, Carden P, Shorter K. Knee wraps affect squat performance. J Strength Cond Res. 2012;8(1):1-16.

9. Marchetti PH, Matos VJP, Soares EG, Silva JJ, Serpa EP, Corrêa DA, et al. Can the technique of knee wrap placement affect the maximal isometric force during back squat exercise? Int J Sports Med 2015;5(1):16-8. 10. Eng J. Sample Size Estimation: How many individuals should be studied? Radiology. 2003;227(2):309-13

11. Maulder P, Cronin J. Horizontal and vertical jump assessment: reliability, symmetry, discriminative and predictive ability. Phys Ther Sport. 2005;6(2):74-82.

12. Brown LE, Weir JP. ASEP Procedures recommendation I: Accurate assessment of muscular strength and power. J Exerc Physiol. 2001;4(3):1-21.

13. Marchetti PH, Arruda CC, Segamarchi LF, Soares EG, Ito DT, Luz Junior DA, et al. Exercício supino: uma breve revisão sobre os aspectos biomecânicos. Brazil. J. of Sports and Exerc. Res. 2010;1 (2):135-42.

14. Wagner LL, Evans SA, Weir JP, Housh TJ, Johnson GO. The effect of grip width on bench press performance. J Appl Biomech. 1992;8(1):1-10.

15. Uchida MC, Teixeira LFM, Godoi VJ, Marchetti PH, Conte M, Coutts AJ, et al. Does the timing of measurement alter session-RPE in boxers? J Sports Sci Med. 2014;13(1):59-65.

16. Day ML, McGuigan MR, Brice G, Foster C. Monitoring exercise intensity during resistance training using the session RPE scale. J Strength Cond Res. 2004;18(2):353-8.

17. Rhea MR. Determining the magnitude of treatment effects in strength training research through the use of the effect size. J Strength Cond Res. 2004;18(4):918-20.

18. Tiggemann CL, Pinto RS, Kruel LFM. A percepção de Esforço no Treinamento de Força. Rev Bras Med Esporte. 2010;16(4):301-9. 